Boletín de la Asociación de Geógrafos Españoles, 78, 49-65

ISSN: 0212-9426 elSSN: 2605-3322

DOI link: http://dx.doi.org/10.21138/bage. 2711

How to cite this work: Galí Espelt, N., \& Donaire Benito, J. A. (2018). First-time versus repeat visitors' behavior patterns: a GPS analysis. Boletín de la Asociación de Geógrafos Españoles, 78, 49-65. doi: http://dx.doi.org/10.21138/bage.2711

\title{
First-time versus repeat visitors' behavior patterns: a GPS analysis
}

El comportamiento espacial de los visitantes de primera visita versus los visitantes repetidores: un análisis con GPS

\author{
Núria Galí Espelt \\ nuria.gali@udg.edu \\ José A. Donaire Benito \\ ja.donaire@udg.edu \\ Facultad de Turismo \\ University of Girona (Spain)
}

\begin{abstract}
Past research conducted on visitors' behavior has highlighted the differences between first-time and repeat visitors in urban and natural settings. To determine whether these differences also exist in a monumental city, we have studied visitor behavior in the historic city of Girona (Spain). Data from 1288 GPS tracking were recorded. Of these, 928 were first-ime visitors, and the remaining 360 corresponded to repeat visitors. Findings show that there is very little difference in how first-time and repeat visitors act, compared to visitor behavior in other types of tourist destinations. Nevertheless, the results do demonstrate differences between low frequency visitors (between 1 and 4 visits) and high frequency visitors (more than 4 visits). These results suggest that sightseeing creates very homogeneous behavior pattern between first-time and repeat visitors, and highlight the need to differentiate repeat visitors according to the number of visits done in the monumental city.
\end{abstract}

Key words: first-time visitor; repeater; direct observation; GPS; tourist behavior. 


\section{Resumen}

Anteriores investigaciones realizadas sobre el comportamiento de los visitantes, en entornos urbanos y naturales, han puesto de manifiesto las diferencias existentes entre los visitantes de primera visita y los repetidores. Para determinar si estas diferencias también existen en una ciudad monumental, hemos estudiado el comportamiento de los visitantes en la ciudad histórica de Girona (España). Se han recopilado 1288 tracks realizados con GPS, 928 fueron de visitantes de primera visita, y 360 correspondieron a visitantes repetidores. El estudio muestra que hay muy pocas diferencias entre repetidores y visitantes de primera visita, en comparación con lo que otros estudios en otro tipo de destinos turísticos han demostrado. Sin embargo, los resultados presentan diferencias entre los visitantes de baja frecuencia (entre 1 y 4 visitas) y los visitantes de alta frecuencia (más de 4 visitas). En definitiva, estos resultados sugieren que el turismo crea un patrón de comportamiento muy homogéneo entre los visitantes de primera visita y los que vuelven a repetir, y resalta la necesidad de diferenciar a los visitantes repetidos de acuerdo al número de visitas realizadas en la ciudad monumental.

Palabras clave: visitante de primera visita; repetidor; observación directa; GPS; comportamiento turístico.

\section{Introduction}

There is agreement in the academic literature that a difference between first-ime and repeat visitors exists. These differences refer to the traveller's motivation, interests, activities done, previous experience and level of knowledge, among others (Lau \& McKercher, 2004; Li, Cheng, Kim \& Petrick, 2008; McKercher, Shoval, Ng \& Birenboim, 2012). According to this criterion, tourism marketing and management ought to be able to offer products adapted to the needs of each group. Therefore it is critical to have in-depth knowledge of differences and similarities in behavior patterns between the groups. These particularly concern itineraries followed, sites visited, time spent on the visit, and travel experience, all of them essential in order to develop effective marketing and management strategies for the destination (Li, Cheng, Kim \& Petrick, 2008).

Most studies contrasting behavior patterns between first-time and repeat visitors have been carried out in large cities (Lau \& McKercher, 2004; McKercher et al., 2012), or in regions or countries (Fakeye \& Crompton, 1991; Oppermann, 1997; Petrick, 2004; Li et al., 2008). Literature on smaller cities or their historic centers is scarce. These smaller cities and historic centers are mainly visited by first-timers, while large cities and regions tend to be visited equally by both first-timers and repeaters (Lau \& McKercher, 2004).

In recent years, using Global Positioning Systems (GPS) to track tourist behavior has become an established practice, due to the fact that they can gather spatial data over a wide area. Edward and 
Griffin (2013) used GPS tracking in their research on spatial behavior of tourists in Sydney and Melbourne. Beeco et al. (2013) analyzed the spatial behavior of clusters of visitors in two counties in Virginia. Petterson and Zillinger (2011) studies the behavior of visitors at the World Championships in Östersund. McKercher et al. (2012), compared the behavior of first-time and repeat visitors in the city of Hong Kong.

Our aim is to examine the differences and similarities in tourist behavior between first-time and repeat visitors to monumental sites, using global positioning systems (GPS). We analyze data gathering from 1288 tracking undertaken in the historic center of Girona (Spain). GPS allow both automatic and systemic data recording of information regarding total length of visit, time spent visiting each node, average speed of visit, length of visit, itinerary followed, and so on (Shoval and Isaacson 2007), creating space-time models with reliable and accurate results. GPS tracking shows where tourists have really been, instead of where they say they have been (which is current problem with some investigations on tourism behavior).

\section{Literature review}

\subsection{First-time and repeat tourists}

In the past two decades, several significant studies have identified similarities and differences in behavior patterns between first-time and repeat visitors (Tiefenbacher, Day \& Walton, 2000; Kozak, 2001; Lau \& McKercher, 2004; McKercher \& Wong, 2004; Li et al., 2008; McKercher et al., 2012). There is no apparent coherent pattern in these similarities and differences when it comes to how either group of first-time or repeat tourists proceed (Li et al., 2008). However there are constants in how each group behaves. On one hand, first-time visitors are very active. They look for what is new and different, new experiences, visit more sites (Oppermann, 1997; Letho, O'Leary \& Morrison, 2004; Li et al., 2008) and sites that are considered more iconic (Li et al., 2008). Repeaters, on the other hand, are more inclined towards relaxation and friendlier behavior (Pyo, Song \& Chang, 1998; Tiefenbacher, Day \& Walton 2000), resulting from previous experience at the destination (Letho et al., 2004). They do fewer activities and visit fewer sites, and they feel less pressurized to visit the iconic sites at the destination (Tiefenbacher et al., 2000; Lau \& McKercher, 2004). Letho et al. (2004) point out that when a tourist visits a place for the first time, they tend to show a more general interest, attempting to visit and experience the country as a whole. In contrast, repeat visitors are more interested in visiting specific places and doing particular activities in greater depth. The authors consider this as an evolution of tourist behavior. The visitor goes from being a generalist to becoming a specialist, from an accidental tourist to a loyal one (Letho et al., 2004, p. 813). Tiefenbacher et al. (2000) suggest that the repeater spends more time at the destination than the first-time visitor. 
Also, the level of expectation is different between one group and another. Those visiting for the first time have lower expectations, as they are not familiar with the destination. On the other hand, repeat visitors tend to be much more satisfied with the visit, due to their commitment to the destination (Kozak, 2001; Li et al., 2008). The need for information is also different between one type of visitor and the other. Pyo, Song and Chang (1998), comparing information sources used by tourists visiting the island of Cheju (Korea), discovered that as the frequency of visits increases, more detailed and reliable information was required. Additionally, first or second time visitors obtain information from mainly travel agencies, whereas repeat visitors use much more informal information sources such as friends, family and work colleagues.

\subsection{Direct non-participant observation for the study of tourist behavior}

Direct observation is one of the best methods for studying tourist behavior, as it provides large quantities of detailed information on the interaction between subject and object (Donaire, Gali \& Royo, 2015). This means it offers real, exact information on the relationship between visitors and the place visited. It is also a very effective method to reduce the distance between the behavior tourists' recount and their real behavior. Direct observation method may be participant, when the researcher is part of the observing tourist or group, or non-participant when the researcher is observing the visitor without actually accompanying them during the visit.

Direct non-participant observation can be done in two ways: in the first one the researcher observes the tourist from a safe distance, making sure they are not aware they are being watched. One of the main references in non-participant observation is Hartmann (1988). The author followed and observed a small group of young American and Canadian tourists during one hour periods in the main city square in Munich. Keul and Küheberger (1997) observed tourists in Salzburg for fifteenminute periods in different time slots. Galí and Donaire (2006) studied the behavior patterns of visitors to the historic center of Girona (Spain), following tourists on their routes and gathering basic information on their behavior from a valued graph. This procedure of observing from a distance has problems, however. Firstly, it is expensive to undertake. Secondly, tracking visitors is time consuming (taking up to six hours at a time). Finally, the presence and active involvement on the part of the researcher in the field study also takes time and effort. Some academics, in an attempt to cut costs, in addition to time and direct involvement in data collection, have opted for other recording systems such as aerial photographs or video recordings (Hartmann, 1988; Petterson \& Zillinger, 2011).

The second way is based on the use of new technologies (GPS, mobile phones, tablets, and so on) makes it possible to collect information in an automatic systematic way (Shoval \& Isaacson, 2007), creating very precise space-time models. In addition, the data can be analyzed easily using geographic information systems (GIS). This enables mapping of the social uses of the tourist site as well as access flows, tourist flows, high-density areas and open spaces. The global positioning 
system, or GPS, is among the technologies most employed by researchers (Shoval \& Isaacson, 2006, 2007; Chhetri \& Arrowsmith, 2008; Tchetchick et al., 2009; Pettersson \& Zillinger, 2011; Svensson et al., 2011; Mckercher et al., 2012; Wolf et al., 2012; Hallo et al., 2012; Bauder, 2015; Grinberger et al., 2014). It can pinpoint the location of a tourist with a high level of accuracy, and gather a large amount of information (Bauder, 2015).

Studying tourist behavior using GPS technology started to become popular in the first decade of the 21 st century. In terms of number of studies, one of the most common areas is natural spaces (Chhetri \& Arrowsmith, 2008; Svensson et al., 2011; Orellana et al., 2012; Wolf et al., 2012; Smallwood et al., 2012; Hallo et al., 2012). There are also a considerable number of studies on large cities (Shoval et al., 2011; Mckercher et al., 2012; Grinberger et al., 2014), and also on theme parks and on entertainment spaces (Pettersson \& Zillinger, 2011; Birenboim et al., 2013; Brown et al., 2013). There are fewer studies on monumental cities or historic centers. Of the research done in this area, the most relevant is by Shoval and Isaacsson $(2006,2007)$ on the historic center of Jerusalem, Nazareth, Acre and old Jaffa.

There is practically no literature comparing the behavior of first-time visitors to that of repeat visitors using GPS. The only reference is the study done by McKercher et al. (2012) on Hong Kong. In this study, the authors compare and contrast tourist behavior of 233 first-time visitors and 130 repeaters staying in hotels in Kowloon (Hong Kong) over the period of one year.

\section{Methodology}

The aim of the present study is to compare and contrast patterns of tourist behavior between firsttime and repeat visitors to heritage sites, specifically the historical center of Girona (Spain), using data obtained from GPS data loggers.

\subsection{Setting of study}

Girona is a small Spanish city, 90 kilometers north of Barcelona and $60 \mathrm{~km}$ south of the French border (population approximately 100,000). Girona is well known for its rich artistic and historic heritage. The old part of the city is an important medieval quarter. Amongst its attractions is the gothic Cathedral of Santa Maria, the Romanesque Monastery of Saint Peter, the Jewish Quarter, the Arabian Baths, the medieval city Walls, and the multicolored, Florentine-style, houses lining the river. Girona is considered an archetype of middle-sized cultural cities.

More recently, as a result of a growing interest in culture and historic places, and also an increase in short distance trips, the city has become an important center for cultural tourism, despite the current global financial crisis. This way, Girona has consolidated its status as a recognized urban-cultural destination, with the growth of the hotel business and an increased projection of its tourist image. 


\subsection{Research method}

The research method relies on tracking tourists using GPS and non-participant observation. As mentioned, direct observation gives much more detailed information regarding interaction between the object and subject, and between visitors and monumental cities. The data gathered from observation was combined with that gathered from tourists using a questionnaire. As soon as the tourists finished the visit, they completed a self-administered questionnaire on the socio-demographic characteristics of the visitor, and the visit, and also on destination image. Both registers were connected through an identifier, in a way that linked the tourists' spatial behavior with their characteristics.

Data were gathered between February and December 2013, with a total of 1368 tracking and questionnaires. Of these, 80 were rejected due to problems with satellite cover and/or technical errors. The final sample was of 1288 cases: 928 of which were first-time visitors (72\%) and 360 cases of repeat visitors (28\%). Each visitor group carried only one GPS, whether it was individual, a couple, or a group travelling together. The GPS were distributed in three focal points:

(1) Primarily, and mainly, from the Tourist Information Office.

(2) Secondly, a small percentage was channeled through the local tour guides that accompany organized groups.

(3) Finally, another small percentage were distributed using an observer who was asked to pick up a tourist and follow him. It was intended to track tourists who were neither accompanied by a guide, nor had passed by the Tourist Information Office. In these cases the researcher carried the GPS, not the tourist.

The GPS was a model QStarz Data Logger (BT-Q1000XT/TR-Q1000XT). The logger was programmed to register the visitor's position every two seconds, using latitude and longitude coordinates, thus providing an accurate, detailed account of their movements in real time. The logger automatically saved the data and was downloaded using a PC (QTravel software) when the tourist returned the GPS. Each GPS had a 72 hour battery life, and was recharged at the Tourist Information Office when not in use.

Data gathered using the GPS was supplemented with a questionnaire, and was completed by the same tourists who carried the GPS (or by the followed tourist or by a group member) once they had finished their visit. The questionnaire gathered basic data on the visit and the visitor and was structured using three types of questions:

(1) Socio-demographic questions.

(2) Questions regarding the visit.

(3) Questions regarding the perceived image of the destination. 
The final sample of tourists observed and the related questionnaires have a confidence level of 95\%, with a margin of error of $3 \%$ and a maximum variability $(p=q=0.5)$. The sample was stratified by months, with the percentage of registers for each month of the year obtained from various sources: Tourist Information Office registers, registers of museums and monuments with an entrance fee, guided tours and central bookings registers.

The main methodological challenge was to break down each tracking into a set of edges. An edge is the section of a street between one intersection and another. Every time a visitor comes to an intersection, they have to make a decision which determines their route. This route is divided into basic units, or edges. Edges are the basic units dividing up the route, and each visitor chooses specific edges and spends an exact amount of time at them. In this way it was possible to know the precise edge used by each visitor and the time spent in them. The second challenge was the physical space studied. Streets in the old center are narrow and winding, making satellite cover poor at times. Consequently, one to one tracks had to be corrected so as not to lose data for later analysis.

Definitely, despite the limitations, the GPS was able to gather objective and accurate data regarding itineraries, visited nodes, visit time in each node and total time spent on the route by tourists, outlining the differences in behavior patterns between repeat visitors and those visiting the city for the first time.

\section{Results}

The main result obtained from the study is that the behavior patterns of first-time visitors and repeaters is practically mimetic. There are no significant differences between one type of visitor and the other. This observation oposes results from other similar studies, which state that when a visitor has previously visited the destination, this influences how they perceive, experience and use the destination. The fact that we found similar behaviour in the two groups is closer to the idea of democratizing desire, when visiting a sight, as argued by McCannell (2011, p. 5):

My interest began when I noticed the monumental indifference of the world's great attractions to social divisions within the multitude of tourists. I am drawn to the peculiar tendency of sightseeing to democratize desire. [...] We are all equal before the attraction.

Many monumental cities are characterized by the fact that the visit is based on visiting monuments. In this case, the range of monuments is limited by a hierarchy of importance, in such a way that it is difficult to avoid the classic visiting pattern. Repeat visitors (much less frequent than in other places) end up doing the same visit they did the first time, whether they intended to or not. The only differences detected are between types of repeater visitors. The study identifies two types of 
repeaters: low frequency repeaters (the visitor who has been to the city two or three times) and high frequency repeaters, who have been to the city more than four times. The differences between the two groups have little relevance when it comes to the nodes visited and the time spent at each node. Differences in how visitors use of the space are more evident.

\subsection{Access to nodes in the city}

There are no significant differences between first-timers and repeaters in their predisposition to visit nodes. The values are practically identical (Table 1). There are no significant differences between first-timers and repeaters in their predisposition to visit nodes. The values are practically identical (Table 1). None of the differences between the percentages of visitors to the monuments are below 0.5. Therefore we can confirm that there is no significant difference between the two groups when it comes to visiting nodes.

Table 1. Percentage of visitors to city sights

\begin{tabular}{|l|c|c|c|c|c|}
\cline { 2 - 6 } \multicolumn{1}{c|}{} & \% first visitors & \% repeaters & chi-square & $\begin{array}{c}\text { Degree of } \\
\text { freedom }\end{array}$ & $\mathrm{P}$ \\
\hline Art Museum & 21.7 & 21.9 & 0.038 & 1 & 0.8453 \\
\hline Sant Felix Church & 51.7 & 50.5 & 1.832 & 1 & 0.1759 \\
\hline History Museum & 4.2 & 4.4 & 0.058 & 1 & 0.8093 \\
\hline Arabian Baths & 41.1 & 41.2 & 0.001 & 1 & 0.9739 \\
\hline Bonastruc ça Porta & 40.4 & 39.8 & 0.475 & 1 & 0.4906 \\
\hline Archeological Walks & 69.4 & 68.5 & 1.251 & 1 & 0.2634 \\
\hline City Walks & 65.1 & 66.7 & 0.081 & 1 & 0.7765 \\
\hline Cathedral & 71.2 & 70.4 & 1.064 & 1 & 0.323 \\
\hline Sant Pere Monastery & 22.3 & 21.2 & 2.285 & 1 & 0.1306 \\
\hline Agullana Palace & 27.1 & 26.7 & 0.257 & 1 & 0.6119 \\
\hline
\end{tabular}

Source: authors

The differences are more significant when we differentiate between low frequency repeaters (1-4 previous visits) and high frequency repeaters (more than 4 visits). Low frequency visitors are more likely to visit more nodes in the city. These findings coincide with those of a study by Pyo, Song y Chang (1998) on visitors to Cheju (Korea). There is, however, one significant difference in the case of city walks, which were much more popular with low-frequency visitors.

Table 2 shows the percentage of visitors to each node in the city, differentiating low frequency repeaters from high frequency ones. The mean number of nodes visited is 4.5. If we distinguish between the three types of tourists, there is no difference between first-time visitors (4.49 nodes), low frequency repeaters (4.72) and high frequency repeaters (4.32). Statistically, the differences between these three groups are not significant. 
Table 2. Percentage of repeat visitors to city sights

\begin{tabular}{|l|c|c|c|c|c|}
\cline { 2 - 6 } \multicolumn{1}{c|}{} & $\begin{array}{c}\text { \% low } \\
\text { frequency }\end{array}$ & $\begin{array}{c}\text { \% high } \\
\text { frequency }\end{array}$ & chi-square & $\begin{array}{c}\text { Degree of } \\
\text { freedom }\end{array}$ & P \\
\hline Art Museum & 24.3 & 16 & 3.336 & 1 & 0.0678 \\
\hline Sant Felix Church & 57 & 50.4 & 1.381 & 1 & 0.2339 \\
\hline History Museum & 5.5 & 2.4 & 1.853 & 1 & 0.1734 \\
\hline Arabian Baths & 41.7 & 40 & 0.097 & 1 & 0.7551 \\
\hline Bonastruc ça Porta & 45.1 & 36 & 2.771 & 1 & 0.096 \\
\hline Archeological Walks & 69.8 & 75.2 & 1.084 & 1 & 0.2979 \\
\hline City Walks & 65.5 & 52.8 & 5.528 & 1 & 0.0187 \\
\hline Cathedral & 73.6 & 72.8 & 0.027 & 1 & 0.8703 \\
\hline Sant Pere Monastery & 24.7 & 25.6 & 0.035 & 1 & 0.8512 \\
\hline Agullana Palace & 30.2 & 24 & 1.552 & 1 & 0.2128 \\
\hline
\end{tabular}

Source: authors

There are no significant differences statistical between time spent on visiting the nodes. The average time spent visiting the set of nodes is 68.8 minutes for the first-time visitors, the average time for low frequency repeaters is 69.5 minutes and 64.8 minutes for the high frequency repeaters. Therefore, low frequency repeaters visit more monuments and spend more time at them, although the differences are minimal.

\subsection{Use of Tourist Space. Access to Edges}

Edges are the sections of streets between one intersection and another, and in urban areas can be identified as if on a map or graph. Edges are very important in visits to monumantal cities, as the route a tourist takes forms part of the whole experience. How visitors use the tourist space combines the route they take through the strees, and the visits to the monuments themselves. This can be rephrased as how they use nodes and edges on a graph. Routes for the three categories (first-time visitors, low frequency repeaters and high frequency repeaters) are shown in Figures 1, 2 and 3. The maps illustrate the tendency in monumental cities to concentrate on the main streets and ignore secondary routes. Edges and nodes are related in a logical way, in that the main nodes create the most frequented routes, and at the same time, the nodes located on these routes are more likely to be visited than those off the main routes. 
Figure 1. Number of visits per edges in the historic city of Girona.

First-time visitors

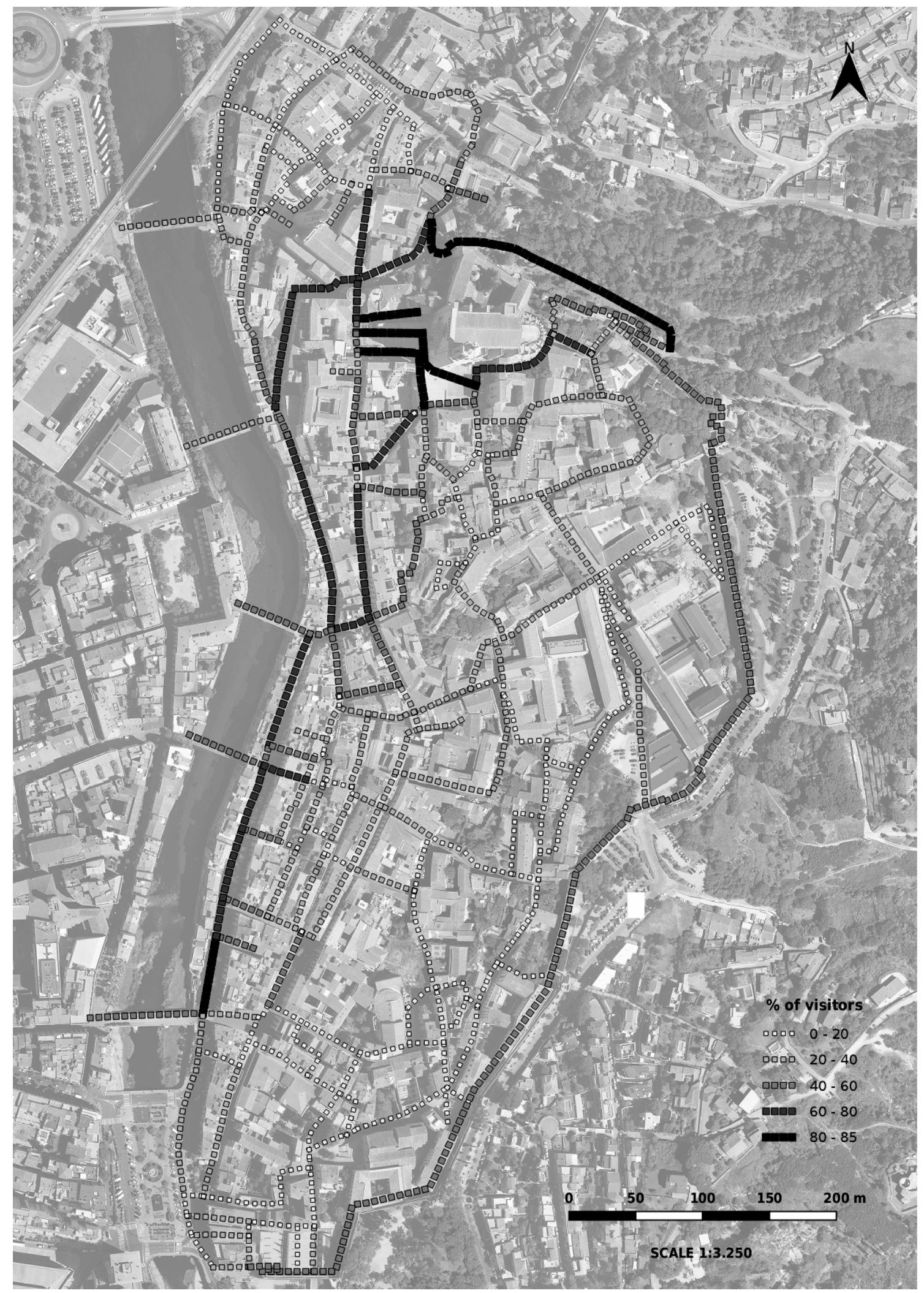

Source: Geographical Information Systems and Remote Sensing Service (SIGTE) of University of Girona (2017) 
Figure 2. Number of visits per edges in the historic city of Girona.

\section{Low frequency repeaters}

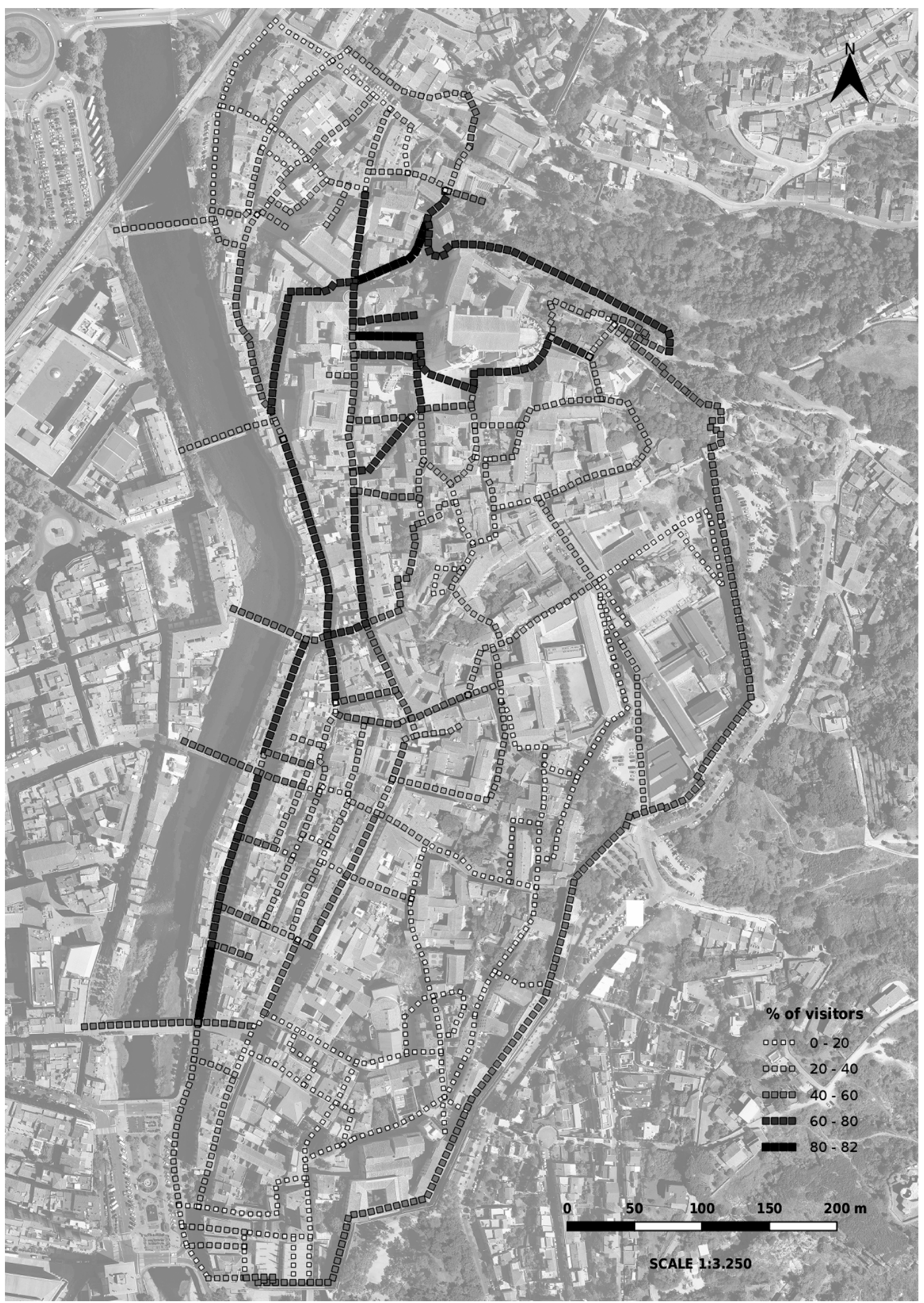

Source: Geographical Information Systems and Remote Sensing Service (SIGTE) of University of Girona (2017) 
Figure 3. Number of visits per edges in the historic city of Girona.

High frequency repeaters

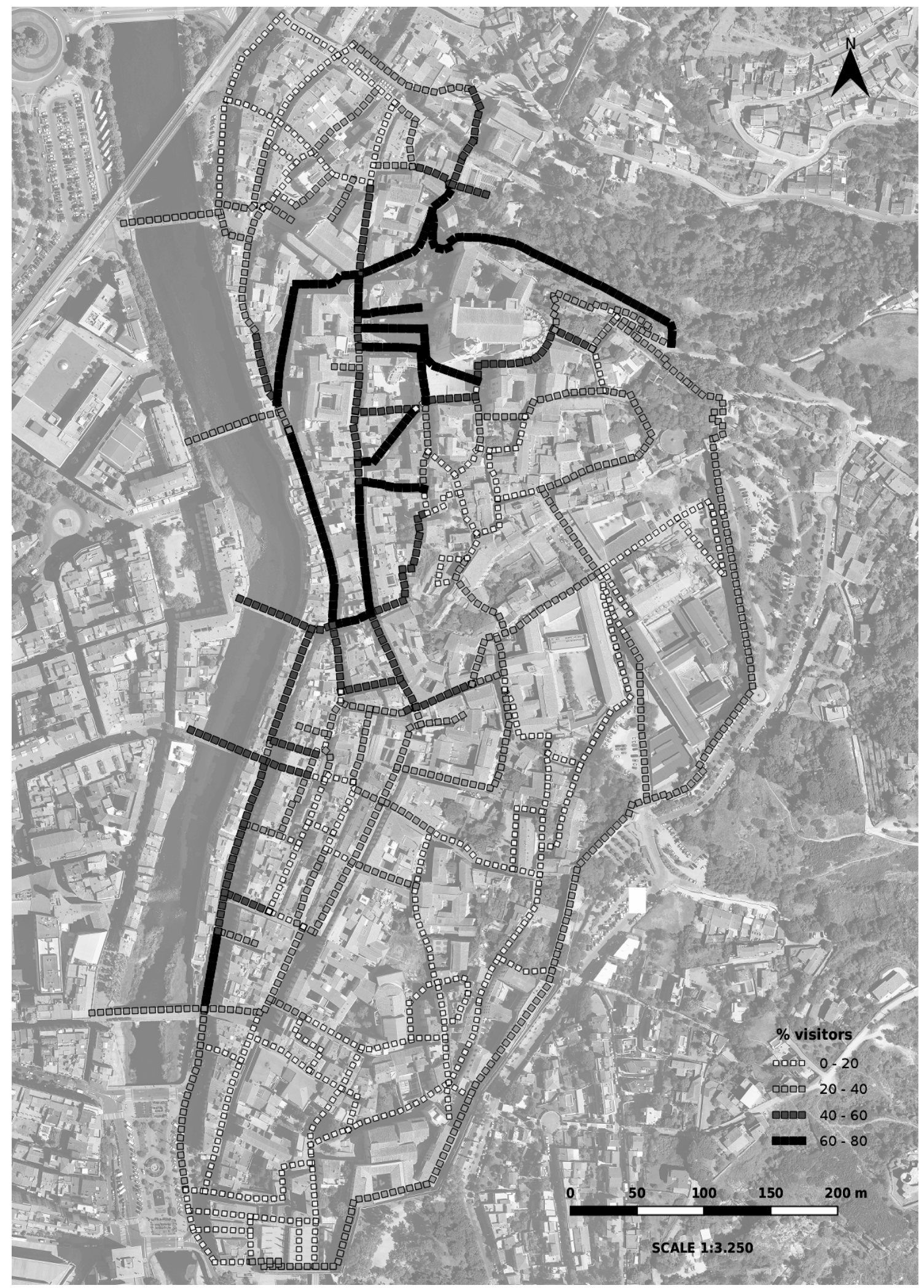

Source: Geographical Information Systems and Remote Sensing Service (SIGTE) of University of Girona (2017) 
In order to determine the differences in how the space is used for each category, each edge is given a value which corresponds to the number of visitors who have passed through it at least once (some edges are used many times by the same visitor). The edges are first organized in four quartiles: Q1 corresponds to the highest number of visits; Q2, the average number of visits; Q3, few visits; and Q4, practically no visits. Percentages for each edge were then calculated. Table 3 compares the results for first-time and repeat visitors. Even though first-time visitors seem to focus more on the most common edges, and repeat visitors tend towards secondary edges, the difference is not significant.

Table 3. Percentage of visitors to city edges

\begin{tabular}{|l|r|r|r|r|}
\cline { 2 - 5 } \multicolumn{1}{c|}{} & \multicolumn{1}{c|}{ Q1 } & \multicolumn{1}{c|}{ Q2 } & \multicolumn{1}{c|}{ Q3 } & \multicolumn{1}{c|}{ Q4 } \\
\hline First visitors & 41.6 & 21.5 & 12.3 & 3.1 \\
\hline Repeaters & 37.8 & 24.5 & 15.3 & 4.2 \\
\hline Chi-square & 1.554 & 1.346 & 2.046 & 0.954 \\
\hline F-Level & 1 & 1 & 1 & 1 \\
\hline P & 0.2126 & 0.246 & 0.1527 & 0.3288 \\
\hline
\end{tabular}

Source: own elaboration

Table 4 shows the results between low frequency repeaters and high frequency repeaters. In this case, the differences are significant in the first and fourth quartile. This data shows that low frequency repeaters look for new routes on repeat visits, even though they visit the same monuments again, as we have already seen. Therefore, the main edges visited have less weight, and secondary edges have significantly more weight. When the number of repeat visits has reached a certain point, visitors choose known routes and follow the standard tourist trail. Therefore, there is a difference between low and high frequency repeaters.

Table 4. Percentage of repeat visitors to city edges

\begin{tabular}{|l|r|r|r|r|}
\cline { 2 - 5 } \multicolumn{1}{c|}{} & \multicolumn{1}{c|}{ Q1 } & \multicolumn{1}{c|}{ Q2 } & Q3 & \multicolumn{1}{c|}{ Q4 } \\
\hline Low frequency & 33.8 & 25.8 & 17.5 & 6.2 \\
\hline High frequency & 45.3 & 22.1 & 11.6 & 0.7 \\
\hline Chi-square & 4.59 & 0.604 & 2.174 & 6.011 \\
\hline F-Level & 1 & 1 & 1 & 1 \\
\hline P & 0.0322 & 0.4372 & 0.1403 & 0.0142 \\
\hline
\end{tabular}

Source: authors

\section{Conclusions}

The results show, above all, how using GPS technology is a reliable, objective, effective and accurate observation method to track and observe tourists' space-time activity patterns. Combining this method with socio-demographic questionnaires on preception and satisfation, reveals notable 
insights into urban tourism. Using GPS loggers also adds deeper knowledge and understanding to differences between first-time and repeat visitor behavior patterns. This is clearly supported by the results.

In short, we demonstrate that differences between first-time and repeat visitors are not as evident as other similar studies have suggested (Oppermann, 1997; Petrick, 2004; Lau \& McKercher, 2004; Li et al., 2008; Mckercher et al., 2012). Sightseeing is standard practice for tourists, regardless of their characteristics, and whether they are first-time or repeat visitors. At the same time, the range of visitor options in a monumental city is not as wide or diverse as those found in other tourist typologies. However, it is revealed that the main differences lie between low and high frequency repeaters. Thus, low frequency repeaters tend to visit different nodes than high frequency repeaters. This result coincides with a study carried out on the island of Cheju (Korea) by Pyo, Song and Chang (1998). The most significant difference relates to itineraries, in that while high frequency repeaters choose conventional routes, low frequency repeaters choose alternative routes.

From a tourism management point of view, this suggests that frequency behavioral differences do not stem from socio-demographic aspects, or from first and second visit, but from loyalty to a destination. For this reason, managers, planners and tourism marketers need to be sensitive to the interests and needs of different levels of frequency of visits to the city. It can be deduced that the tourists who have a very low number of repeat visits to the city have gone beyond the standard model of a visit and look for a deeper and more fulfilling experience. From the moment they exceed a threshold of visits, they become a high repeating visitor, and the relationship with the tourist area is more superficial. These findings suggest the need to differentiate repeat visitors depending on the number of visits done in the monumental area. According to this criterion, tourism marketing and management in small heritage cities ought to be able to offer products adapted to low frequency visitors and high frequency visitors.

Acknowledgments: This research was supported by the Ministry of Economy and Competitiveness (State Secretariat for Research, Development and Innovation) in Spain under Grant CSO201126634.

Authorship statement: The authors declare no conflict of interest. N. Galí and J. A. Donaire conceived and designed the research methodology. N. Gali was responsible of the data gathered. J. A. Donaire performed the data analysis. The maps were done by the Geographical Information Systems and Remote Sensing Service (SIGTE) of University of Girona, funded with resources from a MINECO grant. The final manuscript was produced by the two authors. The authors have given approval to the final version of the manuscript. 


\section{References}

Beeco, J. A., Huang, W. J., Hallo, J. C., Norman, W. C., Mcgehee, N. G., Mcgee, J., \& Goetcheus, C. (2013). GPS tracking of travel routes of wanderers and planners. Tourism Geographies, 15(3), 551-573. doi: http://dx.doi.org/10.1080/14616688.2012.726267

Bauder, M. (2015). Using GPS Supported Speed Analysis to Determine Spatial Visitor Behavior. International Journal of Tourism Research, 17(4), 337-346. doi: http://dx.doi.org/10.1002/jtr. 1991

Birenboim, A., Antón, S., Russo, A. P., \& Shoval, N. (2013). Temporal Activity Patterns of Theme Park Visitors. Tourism Geographies, 601-619. doi: http://dx.doi.org/10.1080/14616688.2012.762540

Brown, A., Kappes, J., \& Marks, J. (2013). Mitigating Theme Park Crowding with Incentives and Information on Mobile Devices. Journal of Travel Research, 52(4), 426-436. doi: http://dx.doi.org/10.1177/0047287512475216

Chhetri, P., \& Arrowsmith, C. (2008). GIS-based Modelling Recreational Potential of Nature-Based Tourist Destinations. Tourism Geographies, 10(2), 233-257. doi: http://dx.doi.org/10.1080/14616680802000089

Donaire, J. A., Galí, N., \& Royo, M. (2015). El uso de GPS para el análisis del comportamiento espacio-temporal de los turistas. Pre-test en el Valle de Boí. Cuadernos de Turismo, 35,117-131. doi: http://dx.doi.org/10.6018/turismo.35.221541

Edwards, D., \& Griffin, T. (2013). Understanding tourists' spatial behaviour: GPS tracking as an aid to sustainable destination management. Journal of Sustainable Tourism, 21(4), 580-595. doi: http://dx.doi.org/10.1080/09669582.2013.776063

Fakeye, P. C., \& Crompton, J. L. (1991). Images Differences between Prospective, First-Time, and Repeat Visitors to the Lower Rio Grande Valley. Journal of Travel Research, 30(2), 10-16. doi: http://dx.doi.org/10.1177/004728759103000202

Galí, N., \& Donaire, J. A. (2006). Visitor's behavior in Heritage Cities: The Case of Girona. Journal of Travel Research, 44(4), 442-448. doi: http://dx.doi.org/10.1177/0047287505282956

Grinberger, A. Y., Shoval, N., \& Mckercher, B. (2014). Typologies of tourists' time-space consumption: A new approach using GPS data and GIS tools. Tourism Geographies, 16(1), 105123. doi: http://dx.doi.org/10.1080/14616688.2013.869249

Hallo, J., Beeco, J.A., Goetcheus, C., Mcgee, J., Gard, N., \& Norman, W. (2012). GPS as a Method for Assessing Spatial and Temporal Use Distributions of Nature-Based tourists. Journal of Travel Research, 51(5), 591-606. doi: http://dx.doi.org/10.1177/0047287511431325 
Hartmann, R. (1988). Combining Field Methods in Tourism Research. Annals of Tourism Research, 5(1), 88-105. doi: http://dx.doi.org/10.1016/0160-7383(88)90073-4

Keul A., \& Küheberger, A. (1997). Tracking the Salzburg Tourist. Annals of Tourism Research, 24(4), 1008-1012. doi: http://dx.doi.org/10.1016/S0160-7383(97)00038-8

Kozak, M. (2001). Repeaters' Behavior at Two Distinct Destinations. Annals of Tourism Research, 28(3), 784-807. doi: http://dx.doi.org/10.1016/S0160-7383(00)00078-5

Lau, A.L.S., \& Mckercher, B. (2004). Exploration versus Acquisition: A Compaerison of First-Time and Repeat Visitors. Journal of Travel Research, 42, 279-285. doi: http://dx.doi.org/10.1177/0047287503257502

Li, X., Cheng, C-K., Kim, H., \& Petrick, J.F. (2008). A systematic comparison of first-time and repeat visitors via two-phase online survey. Tourism Management, 29, 278-293. doi: http://dx.doi.org/10.1016/j.tourman.2007.03.010

Letho, X.Y., O'leary, J., \& Morrison, A.M. (2004). The effect of prior experience on vacation behavior. Annals of Tourism Research, 31(4), 801-818. doi: http://dx.doi.org/10.1016/j.annals.2004.02.006

Maccannell, D. (2011). The Ethics of Sightseeing. Berkeley \& Los Angeles: University of California Press.

Mckercher, B., Shoval, N., Ng, E., \& Birenboim, A. (2012). First and Repeat Visitor Behavior: GPS Tracking and GIS Analysis in Hong Kong. Tourism Geographies, 14(1), 147-161. doi: http://dx.doi.org/10.1080/14616688.2011.598542

Mckercher, B., \& Wong, D. (2004). Understanding Tourism Behavior: Examining the Combined Effects of Prior Visitation History and Destination Status. Journal of Travel Research, 43(2), 171-179. doi: http://dx.doi.org/10.1177/0047287504268246

Orellana, D., Bregt, A. K., Ligtenberg, A., \& Wachowicz, M. (2012). Exploring visitor movements patterns in natural recreational areas. Tourism Management, 33, 672-682. doi: http://dx.doi.org/10.1016/j.tourman.2011.07.010

Oppermann, M. (1997). First-Time and Repeat Visitors to New Zealand. Tourism Management, 18(3), 177-181. doi: http://dx.doi.org/10.1016/S0261-5177(96)00119-7

Pettersson, R., \& Zillinger, M. (2011). Time and Space in Event Behavior: Tracking Visitors by GPS. Tourism Geographies, 13(1), 1-20. doi: http://dx.doi.org/10.1080/14616688.2010.529932

Petrick, J.F. (2004). First Timers and Repeaters' Perceived Value. Journal of Travel Research, 43, 29-38. doi: http://dx.doi.org/10.1177/0047287504265509 
Pyo, S., Song, J., \& Chang, H. (1998). Implications of Repeat Visitor Patterns: The Cheju Island Case. Tourism Analysis, 3,181-187.

Shoval, N., Mckercher, B., Ng, E., \& Birenboim, A. (2011). Hotel Location and Tourist activity in cities. Annals of Tourism Research, 38(4), 1594-1612. doi: http://dx.doi.org/10.1016/j.annals.2011.02.007

Shoval, N., \& Isaacson, M. (2007). Tracking Tourist in The Digital Age. Annals of Tourism Research, 34(1), 141-159. doi: http://dx.doi.org/10.1016/j.annals.2006.07.007

Shoval, N., \& Isaacson, M. (2006). Application of Tracking Tecnologies to the Study of Pedestrian Spatial Behavior. The professional geographer, 58, 172-183. doi: http://dx.doi.org/10.1111/j.1467-9272.2006.00524.x

Smallwood, C.B., Beckley, L.E., \& Moore, S.A. (2012). An analysis of visitor movement patterns using travel networks in a large marine park, north-western Australia. Tourism Management, 33, 517-528. doi: http://dx.doi.org/j.tourman.2011.06.001

Svenson, B., Pettersson, R., \& Zakrisson, I. (2011). Tracking tourists: Mobility, experiences and the supply-demand gap in a Swedish mountain resort. Journal of Tourism Consumption and Practice, 3(2), 1-19.

Tchetchick, A., Fleischer, A., \& Shoval, N. (2009). Segmentation of Visitors to a Heritage Site Using High-resolution Time-space Data. Journal of Travel Research, 48(2), 216-229. doi: http://dx.doi.org/10.1177/0047287509332307

Tiefenbacher, J.P., Day, F.A., \& Walton, J.A. (2000). Attributes of Repeat Visitors to Small TouristOriented Communities. The Social Science Journal, 37(2), 299-308. doi: http://dx.doi.org/10.1016/S0362-3319(00)00063-X

Wolf, I.D., Hagenloh, G., \& Croft, D.B. (2012). Visitors monitoring along roads and hiking trails: How to determine usage levels in tourist sites. Tourism Management, 33, 16-28. doi: http://dx.doi.org/10.1016/S0362-3319(00)00063-X 